
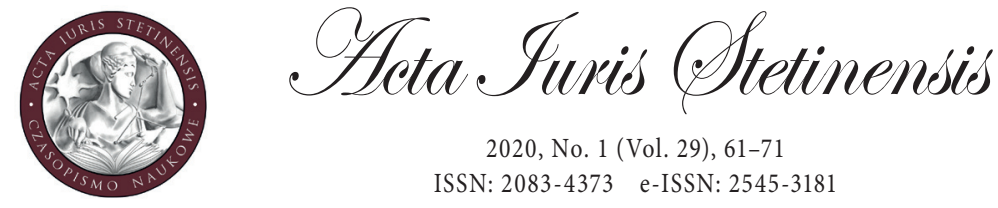

2020, No. 1 (Vol. 29), 61-71

ISSN: 2083-4373 e-ISSN: 2545-3181

DOI: $10.18276 /$ ais.2020.29-05

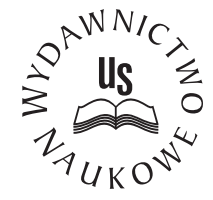

Tadeusz Kołodziej

MA

University of Wrocław, Poland

Faculty of Law and Administration

e-mail: tadeuszjerzykolodziej@gmail.com

ORCID ID: 0000-0003-3811-6706

\title{
Constructivism as a chance to break deadlock in interdisciplinary research combining international law and international relations
}

\begin{abstract}
The purpose of this work is to prove that the theory of constructivism can be an escape from the trap of the constant struggle for influence, which now includes interdisciplinary research combining international law and international relations. For this purpose, the work is divided into three sections. In the first one, the author briefly presents the genesis of interdisciplinary research on international law and international relations. In the second part, the sceptical approach of international law researchers towards combined interdisciplinary research is presented. Also in this section, the theory of constructivism is characterised as a potential area for mutual cooperation between international law and international relations. In the final part, based on the relationship between international humanitarian law and the features of modern weapons, the author tries to prove that the theory of constructivism is perfectly suited to the analysis of contemporary relations between international law and the policies of nations on the international stage.
\end{abstract}

Keywords: constructivism, interdisciplinary research, international humanitarian law, international relations, modern weapons 


\section{Introduction}

In Jan Klabbers' opinion, interdisciplinary research boils down to a dispute between international law (IL) and international relations (IR):

interdisciplinary scholarship is always, and inevitably, about subjection. Interdisciplinary scholarship is, more often than not, about imposing the vocabulary, methods, theories, and idiosyncrasies of discipline A on the work of discipline B. Interdisciplinary scholarship, in a word, is about power, and when it comes to links between international legal scholarship and international relations scholarship, the power balance tilts strongly in favour of the latter. ${ }^{1}$

This article is an attempt to prove that Klabbers' designation of the interdisciplinarity debate does not undermine the sense of interdisciplinary research at all, but rather identifies an obstacle which hindered the development of mutual cooperation between these two scientific disciplines. In the author's opinion, constructivism is the only effective way to break this stagnation. To this end, the author analyses theories of constructivism in terms of its usefulness in interdisciplinary research.

\section{Interdisciplinarity of IL and IR: genesis of cooperation between these disciplines}

The first interaction between the disciplines of IL and IR took place after the First World War, when IR was first recognised as a separate academic discipline. At the beginning, representatives of these two disciplines cooperated closely, not only in a purely academic context, but also practically, in the field of international politics (which resulted in the creation of the League of Nations, for example). ${ }^{2}$ As a result of World War II, the scholarship of realism gained significance. It rejected the idealistic assumptions of IL's and IR's cooperation by emphasising that the norms of IL have no real significance for IR, which in reality are shaped only by the principled interests of states. ${ }^{3}$

The so-called "New Haven School" undermined the assumptions of realists by emphasising the important role of IL as a carrier of certain ideas. In the studies of

1 Klabbers, J., The bridge crack'd: a critical look at interdisciplinary relations, "International Relations" 2009, No. 23(1), p. 120, DOI: 10.1177/004711780810061 (accessed 15.11.2019).

2 Dunoff, J. and Pollack, M., International law and international relations: introducing an interdisciplinary dialogue, New York 2012, pp. 4-6.

3 Slaughter, A., International law and international relations theory: a dual agenda, "American Journal of International Law" 1993, No. 87(2). For more on the role of IL in the scholarship of realism see the second part of the article. 
Myres McDougal and Harold Lasswell, although IL is politicised by nature, it plays a vital role in promoting human dignity. In turn, one of McDougal's students, Richard Falk, pointed out that IL should not promote higher values, but rather the needs and interests of the global society. Falk believed that in the era of a permanent threat of nuclear annihilation, it is in the interest of humanity to maintain stability of the global security system, and thus IL should be subordinated to this goal. ${ }^{4}$

IR scholars have also tried to create a theoretical framework for interdisciplinary research which would link IL with IR. For example, Anne-Marie Slaughter, in her work International law and international relations theory: a dual agenda, comprehensively analyses the issue of interdisciplinarity, and emphasises that cooperation between IR and IL should be natural because both disciplines occupy the same conceptual space. She also pointed to two theories of IR which in her opinion ought to be the starting point for the future cooperation of the two disciplines: liberal theory and institutional theory. Nevertheless, Slaughter ultimately emphasises that the theory which can best be used to build interdisciplinary research is a liberal theory. In her opinion, the liberal theory appreciates the role of IL as a factor which harmonises relations between states. ${ }^{5}$ In turn, another concept developed by the IR scholarship - constructivism, which perceives IL as the normative backbone of IR - is in the author's opinion the only effective way to avoid the fight for influence between IL and IR. A detailed description of constructivism, as well as an explanation of its key importance for the potential development of interdisciplinary research, will be presented in the second part of the article.

\section{Constructivism as an opportunity to overcome the deadlock in interdisciplinary research}

In this section, the interdisciplinary nature of IR and IL research as a dispute over influences will be outlined. Then, the theory of constructivism will be presented as the most sensible way out of this dispute and as proof that interdisciplinary cooperation between IL and IR is possible.

\section{Marginalisation of the role of IL according to IR scholarship}

As the basis of the dispute between IL and IR, Klabbers considers the perception of interdisciplinarity from the perspective of cooperation between IL and the realism

4 Dunoff, J. and Pollack M., op. cit., pp. 5-10.

5 Slaughter, A., op. cit. 
theory of IR. ${ }^{6}$ The realism theory of IR assumes that IL does not play any significant role in international relations. The realists believe in the existence of an anarchic system in relations between states, in which there are constant clashes caused by their different interests. This theory emphasises that states refer to IL only when it coincides with their particular political interests. ${ }^{7}$ In Klabbers' opinion, the juxtaposition of IL with realism results from the need for lawyers to prove the usefulness and importance of IL: "If a lawyer can overcome a realist objection, she can overcome any objection." $\mathrm{He}$ also emphasises that interdisciplinary cooperation of IL with the theory of realism increases its importance in the eyes of the international leaders who perceive IL only as a tool for implementing their policy: "Law will only be taken seriously if statesmen take it seriously, and they won't do so unless the law is made attractive to them, as something they can use as they see fit." 9

Klabbers discusses Slaughter's concept of "the same conceptual space" which IR and IL share. In his text, The bridge crack'd: a critical look at interdisciplinary relations, he emphasised that sharing the same conceptual space not only means describing the same phenomena, but also "ask[ing] a similar question and employ[ing] similar methodologies." ${ }^{10}$ He pointed out that using the conceptual tools of IR in IL research would be pointless because IR and IL have nothing in common: "the two disciplines have as much in common as the musicologist studying Mozart's string quartets, and the gentleman at the ticket-counter trying to sell tickets to next month's performance of Die Zauberflöte: both somehow have to do with Mozart, but that is about it." ${ }^{11}$ Klabbers also briefly presented his opinion about interdisciplinary teaching by pointing out that although academics ought to have some general knowledge about neighbouring scientific disciplines, they should specialise in only one academic field. ${ }^{12}$

The need to fight for the preservation of the subjectivity of IL in relation to the realism theory, in which states are guided solely by their own interests, is also stressed by M. Koskenniemi: "The fight for an international Rule of Law is a fight against politics, understood as a matter of furthering subjective desires and leading

6 Klabbers, J., The relative autonomy of international law or the forgotten politics of interdisciplinarity, "Journal of International Law \& International Relations" 2004, No. 1(35), p. 38.

7 Klabbers, J., International law, Cambridge 2017, p. 16.

8 Klabbers, J., The relative autonomy..., p. 38.

9 Ibidem, pp. 37-38.

10 Klabbers, J., The bridge crack'd..., p. 120.

11 Ibidem, p. 120.

12 Klabbers, J., The relative autonomy..., p. 36. 
into an international anarchy." ${ }^{13}$ According to Koskenniemi, other theories of IR, such as institutionalism and liberalism, which could hypothetically be a foundation for interdisciplinary research, also violate the autonomy of IL by calling for it to be made informal. In his opinion, modern IR perceives the formal requirements of IL as an "obstacle to effective action." The call to deformalise both substantive and procedural IL aims to increase its practical utility, even at the expense of its credibility, "in other words, if the «dual agenda» were only about what works, it would achieve a thoroughly function-dependent, non-autonomous law, an ingenious justification for a world Leviathan." ${ }^{14}$ Concerns about the loss of autonomy by IL due to close cooperation with IR have also been raised by other researchers of IL. ${ }^{15}$

\section{Constructivism as an opportunity to break the deadlock}

Despite the strong criticism of the interdisciplinary cooperation between IL and IR by international lawyers, in the author's opinion there is a field of mutual cooperation and it is constituted by the constructive theory of IR. It is constructivism that "one of the most ardent critics of interdisciplinarity research"16 - Klabbers - points out as the only acceptable one in combined research on IL and IR, which in itself prompts a closer look at this concept as the basis for interdisciplinary research. ${ }^{17}$

Constructivism was born as a theory in opposition to the theories of neorealism and neoliberalism in IR, and by some scholars it is sometimes considered to be the third "great theory" of contemporary international relations. ${ }^{18}$ At the root of neorealism and neoliberalism is the joint assumption that both the actions of states and the rationality of their decisions are uniform. Both neorealism and neoliberalism assume that the attitudes of states can be examined in advance, and a certain pattern of potential behaviour can be created. Constructivism, in turn, holds that

13 Koskenniemi, M., The politics of international law, "European Journal of International Law" 1990, No. 20(1), p. 5.

14 Koskenniemi M., The gentle civilizer of nations: the rise and fall of international law 1870-1960, Cambridge 2009, pp. 486-490.

15 See e.g.: Byers, M., Taking the law out of international law: a critique of the iterative perspective, "Harvard International Law Journal" 1997, No. 38(1).

16 Aalberts, T. and Venzke, I., Moving beyond interdisciplinary turf wars, in: d'Aspremont, J., et al. (eds.), International law as a profession, Cambridge 2017, p. 287.

17 "That is not to say that there is no common ground whatsoever: constructivist work in international relations (...) makes that some common ground exists" - Klabbers, J., The bridge crack'd..., p. 121.

18 Klabbers, J., Review of The status of law in world society: meditations on the role and rule of law by Friedrich Kratochwil, "European Journal of International Law” 2015, No. 25(4). 
the social world is not just a set of certain permanent factors, but that it is created by the attitudes and actions of its participants. ${ }^{19}$ Constructivism is sometimes considered an idealistic concept because it assumes that in a particular social reality (in this case in the area of international politics) the behaviour of entities is shaped by values and ideas. ${ }^{20}$

As part of the theory of constructivism, we can distinguish its specific subtypes. Jeffrey Checkel, in his article Constructivist approaches to European integration, points to three main currents in the research on the theory of constructivism. "Interpretative constructivism," which is particularly popular in Europe, focusses on the impact of various types of language techniques, on the identity of societies and, consequently, on the attitudes of states. As part of the research methodology, this subtype of constructivism focusses on written sources that allow us to reconstruct the identities of a given society and the attitude of the state in a given period. Also, researchers of "critical/radical constructivism" attach great importance to language, which forms the basis of their analysis, as in the case of interpretative constructivism. However, they add the impact of norms on the attitudes of individual countries. ${ }^{21}$ In the context of radical constructivism, an interesting supplement to research on linguistic techniques and the impact of norms on society is the position of Siegfried Schmidt, who extends the field of interest of radical constructivism to include the mass media. ${ }^{22}$ Relationships between norms and the attitudes of states in the international arena are the foundation of "conventional constructivism," the most common research methodology within the framework of constructivism. In this article, the possibility of interdisciplinary rapprochement will be studied based on conventional constructivism. ${ }^{23}$

Nicholas Onuf and Friedrich Kratochwil should be included among the creators of the theory of constructivism; they highlighted the key role of IL in creating "normative structures." ${ }^{24}$ Normative structures, by interacting with material factors (e.g. the geopolitical situation or changing economic conditions) and ideological factors

19 Widłak, T., Prawo a konstruktywizm w teorii stosunków międzynarodowych - możliwości interdyscyplinarnego zbliżenia, in: Bekrycht, T. et al. (eds.), Integracja zewnętrzna i wewnętrzna nauk prawnych, Łódź 2014, pp. 55-56.

20 Czaputowicz, J., Teorie stosunków międzynarodowych, Warszawa 2008, p. 294.

21 Checkel, J., Constructivist approaches to European integration, Oslo 2005, pp. 4-7.

22 Hug, T., Constructivism and media socialization concepts and perspectives in German-speaking countries, "Constructivist Foundations" 2009, No. 2(4), p. 76.

23 Checkel, J., Constructivist approaches..., pp. 5-6.

24 See: Onuf, N., World of our making: rules and rule in social theory and international relations, London 2012; Kratochwil, F., Rules, norms and decisions: on the conditions of practical and legal reasoning in international relations and domestic affairs, Cambridge 2011. 
(the interests and identity of a given state), shape international policy. ${ }^{25}$ Jutta Brunnee and Stephen Toope, in their book Legitimacy and legality in international law: an international account, which is based on the theory of constructivism, pointed out that the validity of these norms depend on reciprocity in their observance, and not, as in the case of national law, on the institution of coercion. Drawing attention to "reciprocity" as key to the functioning of IL highlights the element of interaction between states within IL. ${ }^{26}$ At the root of the theory of constructivism is also a new look at the institution of anarchy in interstate relations presented by Alexander Wendt in the article Anarchy is what states make of it: the social construction of power politics. Wendt undermined the current concept of anarchy seen only as a system of competition between states, stating that the original relationship between them can be based not solely on aggression, but instead on cooperation or indifference. ${ }^{27}$

In the constructive theory of IR, two characteristic aspects allow us to believe that this particular concept can overcome the reluctance of international lawyers to carry out interdisciplinary research combining IL and IR. The first and at the same time key issue is the fact that the theory of constructivism properly appreciates the vital role of norms in shaping the attitude of states in the international arena. The state in the theory of constructivism is both the addressee and the creator of the norm. At the same time, by creating such norms it builds its own identity and shapes its interests, which affects its attitude in the international arena. This theory, in contrast to the liberal theory, allows us to see the role of the norm not only under conditions of peace and mutual cooperation, but also in the case of a conflict between states. ${ }^{28}$ An illustration of the impact of international norms on the attitude of states in an armed conflict is the desire of the intervening states to legalise the act of aggression. One example would be the attempt by American diplomats to legitimise the United States' military intervention in Iraq in 2003. Despite the fact that the intervention did not obtain the mandate of the UN Security Council, and that the United States ultimately committed an unlawful act of aggression, a number of attempts to legalise the intervention itself are proof of recognition, even by the strongest states, of the important role of norms in global politics. ${ }^{29}$

25 Widłak, T., op. cit, pp. 56-57.

26 Brunnee, J. and Toope, S., Legitimacy and legality in international law: an international account, Cambridge 2010, pp. 132-137.

27 Curanović, A., Konstruktywizm, in: Zięba, R. et al. (eds.), Teorie i podejścia badawcze w nauce o stosunkach międzynarodowych, Warszawa 2015, pp. 107-108.

28 Widłak, T., op. cit., pp. 64-65.

29 Czaputowicz, J., op. cit., p. 317. 
The second issue is the recognition by constructivism that the structures of IL have a normative dimension and are not determined by coercion. The IL system and its participants interact with each other. ${ }^{30}$ An example of this interaction is international humanitarian law (IHL), which initially reflected the political will of the states that had created it. However, it currently affects the specific attitudes of states in the international arena. For example, over the past few decades the way weapons are constructed has changed significantly. Weapons are created with the aim of being as precise as possible, thereby reducing the amount of collateral damage when used. $^{31}$

\section{The relationship between humanitarian law and the development of new weapons as a practical example of the constructivist theory}

In this final part of the paper, the author, by using the relationship between IHL and the development of new weapons as an example, will try to prove that the constructivist theory of IR describes the interaction of state policy and IL in a very apt way.

As presented above, a characteristic feature of constructivism is to emphasise that the state as a subject of IR creates a certain legal norm through a political decision. However, such a legal norm in the long run also begins to affect the policy and the identity or behaviour of the country on the international stage. An example of such a "feedback loop" could be IHL in relation to the arms policy of states. A characteristic feature of IHL is the fact that its observance almost fully depends on the goodwill of states. Thus, from the point of view of, for example, the theory of realism, IHL should not have any impact on actual state policy. ${ }^{32}$

However, by using the example of modern weapons development, it can be seen that specific IHL norms aimed at removing from the battlefield types of weapons that cause unnecessary suffering or additional casualties among civilians actually affect the attitudes of states. The key provisions for restricting the use of and research on weapons that can "cause superfluous injury or unnecessary suffering"33

30 Armstrong, D. et al., International law and international relations, Cambridge 2007, pp. 100-105.

31 The relationship between humanitarian law and the characteristics of modern weapons is presented in the last part of the paper.

32 Kolb, R., Advanced introduction to international humanitarian law, Cheltenham 2014, p. 187.

33 Article 35: "1. In any armed conflict, the right of the Parties to the conflict to choose methods or means of warfare is not unlimited. 2. It is prohibited to employ weapons, projectiles and material and methods of warfare of a nature to cause superfluous injury or unnecessary suffering. 3 . It is prohibited to employ methods or means of warfare which are intended, or may be expected, to cause widespread, long-term and severe damage to the natural environment." Article 35 of the 
were included in Part III, "Methods and means of warfare combatant and prisonerof-war status" of the Additional Protocol I to the Geneva Conventions signed in $1977 .{ }^{34}$ Behind the creation of this regulation was a political decision of the states based on the Vietnam War, among others. During this conflict, the USA used weapons characterised by a lack of precision which resulted in a large number of civilian casualties and unnecessary suffering (i.e. napalm) ${ }^{35}$ In hindsight, it can be assessed that the impact of legal norms resulting from specific articles (e.g. Articles 35 and $36^{36}$ ) of the Additional Protocol I on research and then the use of weapons in the modern battlefield is indisputable. One illustration is the development of weapons focussed on the surgical impact of "Weapons of Precise Destruction," which reduce the number of casualties by reducing the area of attack. ${ }^{37}$

The policy of states, as well as the awareness of the need to create as precise weapons as possible, was changed by a norm of IL. Thus, the assumption of constructivism theory that the states create certain norms which in the long run shape the states' policy has been given practical reflection. Of course, the impact of this particular legal norm on the policy of states participating in various armed conflicts in recent decades has not been the same. Nevertheless, the theory of constructivism also takes this into account, emphasising that ideological factors, such as a political regime or economic situation, also influence the application of some norms. ${ }^{38}$

\section{Conclusions}

Interdisciplinarity in combined studies of IL and IR has never been as straightforward as it might seem at first glance. In the author's opinion, the main obstacle to establishing close, interdisciplinary cooperation was the marginalisation of IL by the theory of realism. Despite many attempts by researchers representing other

Protocol Additional to the Geneva Conventions of 12 August 1949 (Protocol I), https://www.icrc. org/en/doc/assets/files/other/icrc_002_0321.pdf (accessed 24.11.2019).

34 Ibidem.

35 Kolb, R., op. cit., p. 16.

36 Article 36: "In the study, the development, acquisition or adoption of a new weapon, means or method of warfare, a High Contracting Party is under an obligation to determine whether its employment would, in some or all circumstances, be prohibited by this Protocol or by any other rule of international law applicable to the High Contracting Party". Article 36 of the Protocol Additional to the Geneva Conventions of 12 August 1949 (Protocol I), https://www.icrc.org/en/ doc/assets/files/other/icrc_002_0321.pdf (accessed 24.11.2019).

37 For more on the specific technical solutions that reduce the number of bystanders, see Schmitt, M., Precision attack and international humanitarian law, "International Review of the Red Cross" 2005, No. 87, p. 859.

Checkel, J., The constructivist turn in international relations theory, Cambridge 1998, pp. 416-418. 
trends in IR, it has not been possible to create a concept of interdisciplinary research that would inspire the trust of many prominent researchers of IL. The relatively new IR theory, constructivism, which has appreciated the impact of IL on actors of the international system, represents a hope for change. On the one hand, constructivism emphasises the impact of politics on IL, which manifests itself in its establishment, and on the other hand it recognises that legal norms affect the behaviour of states on the international stage. One example of this relationship is the development of modern military systems and weapons in a manner compatible with IHL, i.e. those that enable a precise strike and thus reduce the amount of collateral damage. The establishment of IHL regulations was a political act, while its compliance, despite the lack of top-down constraint, shows that legal norms have an elementary impact on the tradition, attitude, and policy of states.

\section{References}

Aalberts, T. and Venzke I., Moving beyond interdisciplinary turf wars: towards an understanding of international law as practice, in: d'Aspremont, J. et al. (eds.), International law as a profession, Cambridge 2017.

Armstrong, D. et al., International law and international relations, Cambridge 2007.

Byers, M., Taking the law out of international law: a critique of the iterative perspective, "Harvard International Law Journal" 1997, No. 38(1).

Brunnee, J. and Toope S., Legitimacy and legality in international law: an international account, Cambridge 2011.

Checkel, J.T., Constructivist approaches to European integration, Oslo 2005.

Checkel, J.T., The constructivist turn in international relations theory, Cambridge 1998.

Curanović, A., Konstruktywizm, in: Zięba, R. et al. (eds.), Teorie i podejścia badawcze w nauce o stosunkach międzynarodowych, Warszawa 2015.

Czaputowicz, J., Teorie Stosunków Międzynarodowych, Warszawa 2008.

Dunoff, J.L. and Pollack, M.A., International law and international relations: introducing an interdisciplinary dialogue, New York 2012.

Hug, T., Constructivism and media socialization concepts and perspectives in German-speaking countries, "Constructivist Foundations" 2009, No. 2(4).

Klabbers, J., International law, Cambridge 2017.

Klabbers, J., Review of The status of law in world society: meditations on the role and rule of law by Friedrich Kratochwil, "European Journal of International Law" 2015, No. 25(4).

Klabbers, J., The bridge crack'd: a critical look at interdisciplinary relations, "International Relations" 2009, No. 23(1). 
Klabbers, J., The relative autonomy of international law or the forgotten politics of interdisciplinarity, "Journal of International Law \& International Relations" 2004, No. 1(35).

Kolb, R., Advanced introduction to international humanitarian law, Cheltenham 2014.

Koskenniemi, M., The politics of international law, "European Journal of International Law" 1990, No. 20(1).

Koskenniemi, M., The gentle civilizer of nations: the rise and fall of international law 1870-1960, Cambridge 2009.

Kratochwil, F., Rules, norms and decisions: on the conditions of practical and legal reasoning in international relations and domestic affairs, Cambridge 2011.

Onuf, N., World of our making: rules and rule in social theory and international relations, London 2012.

Slaughter, A.M., International law and international relations theory: a dual agenda, “American Journal of International Law” 1993, No. 87(2).

Schmitt, M., Precision attack and international humanitarian law, "International Review of the Red Cross" 2005, No. 87.

Widłak, T., Prawo a konstruktywizm $w$ teorii stosunków międzynarodowych - możliwości interdyscyplinarnego zbliżenia, in: Bekrycht, T. et al. (eds.), Integracja zewnętrzna i wewnętrzna nauk prawnych, Łódź 2014.

\section{CITATION}

KOŁODZIEJ, T., Constructivism as a chance to break deadlock in interdisciplinary research combining international law and international relations, "Acta Iuris Stetinensis" 2020, No. 1 (Vol. 29), 61-71, DOI: 10.18276/ais.2020.29-05. 